\title{
ANALISIS TINGKAT KEPUASAN MAHASISWA TERHADAP PELAYANAN AKADEMIK SEKOLAH TINGGI THEOLOGIA JAFFRAY MAKASSAR
}

\author{
Yonas Boky ${ }^{1)^{*}}$ \\ 1) Alumni Prodi Pendidikan Agama Kristen Sekolah Tinggi Theologia Jaffray \\ *)Penulis korespondensi:yonasboky.sttj@gmail.com
}

\begin{abstract}
Abstrak
Bidang akademik Sekolah Tinggi Theologia Jaffray telah berusaha sebaik mungkin untuk melakukan pelayanan kepada mahasiswa sebagai konsumennya. Namun tidak dapat dipungkiri lagi bahwa selalu saja ada kekurangan dalam pelayanannya sehingga menimbulkan ketidakpuasan dari mahasiswa sebagai pelanggannya. Kenyataannya, kepuasan mahasiswa terhadap pelayanan akademik berbeda-beda. Oleh karena itu tujuan penulisan ini adalah Pertama, untuk menjelaskan sejauh mana tingkat kepuasan mahasiswa Sl terhadap pelayanan bidang akademik Sekolah Tinggi Theologia Jaffray Makassar berdasarkan hierarki kebutuhan Maslow. Kedua, menjelaskan bagaimana bidang akademik Sekolah Tinggi Theologia Jaffray Makassar melaksanakan tugas dan tanggung jawabnya. Strategi untuk meningkatkan kepuasan mahasiswa terhadap layanan Akademik STT Jaffray Makassar adalah perlunya melaksanakan hal-hal yang menjadi prioritas utama, seperti: pelayanan akademik mampu bertindak cepat atas setiap keluhan mahasiswa, adanya evaluasi di bidang akademik sendiri secara rutin untuk melihat sejauh mana tingkat kepuasan mahasiswa itu tercapai, sistem komputerisasi akademik yang sudah berjalan baik walaupun dinilai oleh mahasiswa masih perlu peningkatan lagi. Hal-hal yang harus dipertahankan oleh bidang akademik STT Jaffray Makassar adalah pihak kampus harus terus memberikan keamanan dan kenyamanan kepada mahasiswa, memberikan bimbingan akademik maupun konseling bagi mahasiswa yang mengalami kendala.
\end{abstract}

Kata kunci: hierarki, kepuasan, mahasiswa, kebutuhan, Maslow, akademik, STT Jaffray, Makassar

The academic department of Sekolah Tinggi Theologia Jaffray has striven to minister to students as consumers, the fact is, contentment differs among students toward the service given by academics. Because of this, the purpose of this writing is as follows: First, to explain how high the level of contentment is among bachelor level students towards the services of the department of academics of Sekolah Tinggi Theologia Jaffray based on Maslow's hierarchy of needs. Second, to explain how the academic department at Sekolah Tinggi Theologia Jaffray carries out its tasks and responssibilities. The strategy to raise 
the satisfaction of the students toward the service of Academics at Sekolah Tinggi Theologia Jaffray is to carry out those things that have become the main priorities, such as: academic services is able to responsd quickly to every student complaint, there will be a routine evaluation of the academic department alone to see how far the level of student satisfaction has been reached, an academic computer system that, although has already been running, according to students, needs to be improved. Those things that need to be maintained by the academic department of Sekolah Tinggi Theologia Jaffray are that the campus must continue to give safety and comfort to its students, give student academic guidance as well as counseling to those students who have experienced obstacles/who have undergone school discipline.

Key words: hierarchy, satisfaction, student, need, Maslow, academic, STT Jaffray, Makassar

\section{Pendahuluan}

Pelayanan akademik yang berkualitas akan menciptakan manusia atau mahasiswa yang berkualitas pula dan mampu bersaing diera globalisasi. Kepuasan mahasiswa menjadi tolak ukur suatu perguruan tinggi dalam melakukan pelayanan kepada mahasiswa. Pelayanan yang terbaik harus mampu diberikan oleh bidang akademik di segala aspek. Menurut Tampubolon, pelayanan akademik yang kadang disebut dengan pelayanan kurikuler, meliputi: peraturan akademik, perkuliahan, kurikulum, bimbingan/konsultasi akademik, praktikum, tugas akhir, evaluasi, termasuk alat bantu perkuliahan seperti perpustakaan, OHP, laboratorium, dan lain-lain. ${ }^{1}$ Pelayanan akademik akan berjalan dengan baik jika ditunjang oleh manajemen yang baik pula. Manajemen pada dasarnya merupakan suatu proses penggunaan sumber daya secara efektif untuk mencapai sasaran atau tujuan tertentu. Istilah manajemen biasa dikenal dalam ilmu ekonomi, yang memfokuskan pada profit (keuntungan) dan komoditas komersial. ${ }^{2}$ Oleh karena itu, lembaga pendidikan yang menjalankan tugas dan tanggung jawabnya sebagai sarana penunjang terciptanya sumber daya manusia yang berkompeten dan mampu bersaing di era globalisasi ini, maka institut pendidikan harus mau berbenah diri sesuai dengan kebutuhan zaman sekarang ini.

Siagian dalam bukunya yang berjudul Filsafat Administrasi mengatakan perlu adanya kesatuan arah (Unity Of Direction) artinya bahwa semua kegiatan, semua sumber, semua pemikiran, keahlian,

\footnotetext{
${ }^{\mathrm{l} D a u l a t}$ Purnama Tampubolon, Perguruan Tinggi Bermutu Baru Manajemen Pendidikan Menghadapi Tantangan Abad Ke-2l (Jakarta: Gramedia, 2001), 23.

${ }^{2}$ Muhaimin, Manajemen Pendidikan Aplikasinya Dalam Penyusunan Rencana Pengembangan Sekolah/Madrasah (Jakarta: Kencana, 2010), 31.
} 
waktu, dan kemampuan ditujukan hanya kepada satu arah yaitu pencapaian tujuan dengan cara yang seefisien dan seefektif mungkin. ${ }^{3}$

Sejauh ini bidang akademik Sekolah Tinggi Theologia Jaffray telah berusaha sebaik mungkin untuk melakukan pelayanan kepada mahasiswa sebagai konsumennya. Namun tidak dapat dipungkiri lagi bahwa selalu saja ada kekurangan dalam pelayanannya sehingga menimbulkan ketidakpuasan dari mahasiswa sebagai pelanggannya. Supranto berpendapat bahwa pada dasarnya kepuasan atau ketidakpuasan pelanggan merupakan perbedaan antara harapan dan kinerja suatu barang, sekurang-kurangnya sama dengan apa yang diharapkan. ${ }^{4}$ Menurut Maslow yang pertama berdasarkan kebutuhan fisiologis di mana kebutuhan akan rasa sandang, pangan menjadi terpenuhi. Kebutuhan akan keamanan terjamin dengan adanya jaminan sosial. Kebutuhan akan rasa sosial di mana terciptanya hubungan persahabatan yang baik antar mahasiswa dengan mahasiswa, mahasiswa dengan karyawan. Kebutuhan penghargaan yang diberikan kepada mahasiswa karena prestasi yang dicapainya. Kebutuhan akan aktualisasi diri melalui pengembangan diri mahasiswa agar mampu mengembangkan kemampuan individunya. ${ }^{5}$

Pengertian Kepuasan

Tjiptono dan Chandra dalam buku Manajemen Kualitas Jasa mendefinisikan kepuasan sebagai upaya pemenuhan sesuatu atau membuat sesuatu memadai. Kepuasan akan terjadi jika sesuatu yang dikerjakan itu akan memadai sesuai dengan harapan. ${ }^{6}$ Harald Biong dalam jurnalnya yang berjudul "Satisfaction and Loyalty to Suppliers Within Grocery Trade," European Journal of Marketing menjelaskan bahwa kepuasan sebagai sebuah konsekuensi atau akibat atas pengalaman satu pihak terhadap kemampuan pihak lain untuk memenuhi norma-norma atau aturan-aturan dengan harapan-harapannya. ${ }^{7}$ Abdul-Muhmin dalam Journal of Business \& Industrial Marketing yang berjudul "Effects of Suppliers' Marketing Program Variables on Industrial Buyers' Relationship Satisfaction and Commitment," mendefinisikan kepuasan adalah sebuah keadaan kasih sayang yang positif dihasilkan dari penilaian perusahaan

\footnotetext{
${ }^{3}$ S. P. Siagian, Filsafat Administrasi (Jakarta: Gunung Agung, 1982), 120.

${ }^{4}$ J. Supranto, Metode Riset Aplikasi Dalam Pemasaran (Jakarta: Lembaga Penerbit Fakultas Ekonomi Universitas Indonesia, 1991), 28.

"Teori Hierarki Kebutuhan Maslow," diakses 5 Mei 2016, https://hinadhina39.wordpress.com/2013/04/27/teori-hierarki-kebutuhan-Maslowadd-media-abraham-Maslow/.

${ }^{6}$ Zuliam Yamif, Manajemen Kualitas Produk dan Jasa (Yogyakarta: Ekonisia, 2001), 55.

${ }^{7}$ Zuliam Yamif, Manajemen Kualitas Produk dan Jasa, 56; Harald Biong, "Satisfaction and Loyalty to Suppliers Within Grocery Trade," European Journal of Marketing 27/7 (1993):21-38.
} 
terhadap seluruh aspek dari hubungan dengan konsumen. ${ }^{8}$ Kepuasan menurut Kotler adalah perasaan senang atau kecewa seseorang yang berasal dari perbandingan antara kesannya terhadap kinerja (hasil) sesuatu produk dengan harapannya. ${ }^{9}$ Sedarmayanti mengartikan kepuasan adalah tingkat perasaan seseorang setelah membandingkan kinerja (hasil) yang dirasakan dengan harapannya. ${ }^{10}$ Menurut Day Tse Wilton kepuasan pelanggan merupakan respons terhadap evaluasi ketidaksesuaian yang dirasakan antara kinerja dengan kinerja aktual produk yang dirasakan setelah pemakaiannya. ${ }^{11}$ Pengertian kepuasan pelanggan berarti bahwa kinerja suatu jasa atau barang sekurangkurangnya sama dengan apa yang diharapkan. ${ }^{12}$ Menurut Sugito dalam Iswani dan Yanti, kepuasan mahasiswa adalah suatu keadaan di mana terpenuhinya keinginan, harapan, dan kebutuhan mahasiswa. Jika pelayanan yang diberikan dapat memenuhi keinginan, harapan, dan kebutuhan mahasiswa, maka dapat dinilai pelayanan itu memuaskan, dan sebaliknya, jika pelayanan yang diberikan tidak dapat memenuhi keinginan, harapan, dan kebutuhan mahasiswa, maka dapat disimpulkan pelayanan itu tidak memuaskan. ${ }^{13}$

\section{Pengertian Pelanggan}

Pelanggan adalah semua orang yang menuntut kita atau lembaga untuk memenuhi suatu standar kualitas tertentu, dan karena itu akan berpengaruh pada performansi lembaga. ${ }^{14}$ Pada dasarnya kepuasan pelanggan dapat didefinisikan secara sederhana sebagai suatu keadaan di mana kebutuhan, keinginan, dan harapan pelanggan dapat terpenuhi melalui produk yang dikonsumsi. ${ }^{15}$

${ }^{8}$ Yamif, 57; Kutipan dari Alhassan G. Abdul-Muhmin, "Effects of Suppliers' Marketing Program Variables on Industrial Buyers Relationship Satisfaction and Commitment," Journal of Business and Industrial Marketing 17, No. 7 (2002):637-649.

${ }^{9}$ Philip Kotler, Pemasaran Jasa (Jakarta: Erlangga, 2002), 2.

${ }^{10}$ Sedarmayanti, Reformasi Administrasi Publik, Reformasi Birokrasi, dan Kepemimpinan Masa Depan (Mewujudkan Pelayanan Prima dan Kepemerintahan yang Baik) (Bandung: Refika Aditama, 2009), 264.

${ }^{11}$ F. Tjiptono, Manajemen Jasa (Yogyakarta: ANDI, 1998). 224.

${ }^{12}$ J. Supranto, Pengukuran Tingkat Kepuasan Pelanggan (Jakarta: Rineka Cipta, 2006),

${ }^{13}$ A.Iswani, dan T. S. Yanti. "Analisis Faktor-Faktor Kepuasan Mahasiswa Terhadap Pelayanan Universitas Islam Bandung sebagai Institusi Pendidikan Tinggi," (Makalah yang dipresentasikan pada Prosiding untuk Universitas Islam Bandung, 2011), 449. 56-57.

${ }^{14}$ Edward Sallis, Total Quality Management in Education (Yogyakarta: IRCiSoD, 2007),

${ }^{15}$ Vincent Gaspersz, Total Quality Management (Jakarta: Gramedia, 2008), 33. 
Kata pelanggan sangat akrab dalam dunia bisnis mulai dari pedagang kecil hingga ke pedagang yang besar, setiap orang atau badan tertentu yang berkecimpung di bidang bisnis atau jasa sangat mengerti tentang arti kata pelanggan itu sendiri. "Secara tradisional pelanggan diartikan orang yang membeli dan menggunakan produk. Dalam perusahaan yang bergerak di bidang jasa, pelanggan adalah orang yang menggunakan jasa pelayanan." ${ }^{16}$ Menurut Vincent Gaspersz, pengertian pelanggan adalah semua orang yang menuntut kita untuk memenuhi suatu standar kualitas tertentu, dan oleh karena itu akan memberikan pengaruh pada kinerja atau performansi (performance) kita. ${ }^{17}$

\section{Teori Maslow}

Abraham Maslow dalam Robbins dan Judge mengemukakan bahwa di dalam diri semua manusia bersemayam lima jenjang kebutuhan, yaitu sebagai berikut: ${ }^{18}$

1. Kebutuhan fisiologis: antara lain rasa lapar, haus, perlindungan (pakaian dan perumahan), dan kebutuhan jasmani lainnya. Kepuasan akan terpenuhi dalam diri mahasiswa jika kebutuhan fisiologisnya terpenuhi seperti kebutuhan akan makan, minum, tempat tinggal yang layak (di asrama) serta ruang kuliah yang nyaman.

2. Kebutuhan keamanan: antara lain keselamatan dan perlindungan terhadap kerugian fisik dan emosional. Kepuasan akan terwujud jikamahasiwa sebagai konsumen merasa dilindungi dari berbagai kekerasan baik secara fisik maupun secara emosional.

3. Kebutuhan sosial: mencakup kasih sayang, rasa memiliki, diterima baik, dan persahabatan. Kebutuhan untuk bersosialisasi dengan orang lain dapat diwujudkan melalui keterlibatan seseorang dalam organisasi atau perkumpulan-perkumpulan lainnya.

4. Kebutuhan penghargaan: mencakup faktor penghormatan dari luar seperti misalnya status, pengakuan, dan perhatian. Adanya pengakuan dan perhatian dari orang lain maka seseorang merasa dibutuhkan.

5. Kebutuhan aktualisasi diri: dorongan untuk menjadi seseorang atau sesuatu sesuai ambisinya; yang mencakup pertumbuhan, pencapaian potensi, dan pemenuhan kebutuhan diri.

Teori Maslow berpendapat bahwa seseorang dapat memenuhi kebutuhan pokoknya sebelum memenuhi kebutuhan yang lebih tinggi lainnya. Kebutuhan dasar harus dipenuhi terlebih dulu. Yang terpenting dari pemikiran Maslow adalah ketika kebutuhan dasar sudah terpenuhi

\footnotetext{
${ }^{16}$ Zulhan Yamit, Manajemen Kualitas Produk dan Jasa, 74-75.

${ }^{17}$ Vincent Gaspersz, Penerapan Konsep VINCENT Tentang Kualitas Dalam Manajemen Bisnis Total (Jakarta: Yayasan Indonesia Emas dan Gramedia, 2002), 47-48.

${ }^{18}$ Stephen P. Robbins dan Judge, Perilaku Organisasi (Jakarta: Gramedia, 2006), 214.
} 
maka akan memberikan motivasi bagi seseorang. Kepuasan merupakan kebutuhan manusia, ini terbukti bahwa suatu perguruan tinggi selalu memperhatikan kepuasan para mahasiswanya sebagai konsumen.

\section{Kepuasan Mahasiswa}

Kualitas pelayanan yang diberikan oleh bidang akademik STT Jaffray sebagai penyedia jasa dapat diketahui melalui kepuasan para mahasiswa sebagai pelanggannya. Oleh karena itu, Kepuasan pelanggan bergantung kepada kinerja anggapan produk terhadap ekspektasi pelanggan atau pembeli. Jika kinerja tidak memenuhi ekspektasi, maka pelanggan akan mengalami kekecewaan. Sebaliknya jika kinerja sesuai dengan ekspektasi maka pelanggan mengalami kepuasan, dan jika kinerja melebihi ekspektasi maka pelanggan akan sangat puas. ${ }^{19}$

Trisno Musanto mengutip pendapat Band dalam buku Membangun Kepuasan pelanggan, mengatakan kepuasan pelanggan merupakan tingkatan di mana kebutuhan, keinginan dan harapan dari pelanggan dapat terpenuhi yang mengakibatkan terjadinya pembelian ulang atau kesetiaan. Selain itu Trisno juga mengutip pendapat dari Mowen bahwa kunci terciptanya kepuasan pelanggan terletak pada kinerja yang ditunjukkan oleh agen yang diartikan sebagai kualitas agen tersebut. ${ }^{20}$ Jadi dapat disimpulkan bahwa kepuasan pelanggan berhubungan erat dengan kualitas produk dari penyedia layanan. Selain itu Erwan W. menambahkan bahwa kepuasan konsumen sangat dipengaruhi oleh beberapa hal yang meliputi pengiriman produk, citra perusahaan/ produk/merek/nilai harga yang dihubungkan dengan nilai yang diterima oleh konsumennya. ${ }^{21}$ Kepuasan pelanggan terjadi itu berasal dari kualitas suatu produk, layanan dan harga produk tersebut.

\section{Pengaruh Pelayanan Terhadap Kepuasan}

Pelayanan sangat berpengaruh terhadap kepuasan, pelayanan yang diberikan oleh penyedia jasa dalam membuktikan sesuatu yang tidak nyata menjadi sesuatu yang nyata sehingga konsumen dapat merasakan pelayanan yang diberikan kepada konsumen. Apakah pelayanan tersebut

\footnotetext{
${ }^{19}$ Philip Kotler dan Gary Armstrong, Prinsip-Prinsip Pemasaran Edisi 12 (Jakarta: Erlangga, 2008), 16.

${ }^{20}$ Trisno Musanto, "Faktor-Faktor Kepuasan Pelanggan dan Loyalitas Pelanggan: Studi Kasus pada CV. Sarana Media Advertising Surabaya," Jurnal Manajemen \& Kewirausahaan 6, no. 2 (September 2004): 125; William A. Band, Creating value for customer: Designing and Implementation a Total Corporate Strategy (John Walley and Sons Inc, Canada, 1991).

${ }^{21}$ Erwan W., Manajemen Kualitas Produksi Dan Jasa (Yogyakarta: Ekonisia, 2007), 26.
} 
sesuai dengan harapan atau tidak sesuai dengan harapan bahkan melebihi harapan yang dimiliki oleh konsumen. Fredy Rangkuti mengemukakan bahwa kepuasan pelanggan ditentukan oleh berbagai jenis pelayanan yang didapatkan oleh pelanggan selama ia menggunakan beberapa tahapan pelayanan tersebut. Ketidakpuasan yang diperoleh pada tahap awal pelayanan menimbulkan presepsi berupa kualitas pelayanan yang buruk untuk tahap pelayanan selanjutnya, sehingga pelanggan merasa tidak puas dengan pelayanan secara keseluruhan. ${ }^{22}$ Lupiyoadi mengemukan bahwa dalam menentukan tingkat kepuasan, seseorang pelanggan sering kali melihat dari nilai lebih produk maupun kinerja pelayanan yang dapat diterima dari suatu proses pembelian terhadap produk atau jasa dibandingkan dengan perusahan lain. ${ }^{23}$

Lewat pengalaman diri sendiri maupun teman-teman, brosur, iklan, atau dengan cara lainnya terbentuk harapan konsumen terhadap pelayanan yang diberikan. Pelayanan yang diberikan sesuai dengan harapan konsumen, konsumen akan merasa puas. Fredy Rangkuti berpendapat bahwa situasi pelayanan dikaitkan dengan kondisi internal pelanggan sehingga memengaruhi kinerja pelayanan. Kinerja pelayanan dapat ditentukan oleh: pelayanan, proses pelayanan dan lingkungan fisik di mana pelayanan diberikan. Karena itu, presepsi pelanggan terhadap suatu pelayanan ditentukan oleh ketiga hal di atas. ${ }^{24}$

Oleh karena itu, penyedia jasa harus memberikan pelayanan dan jasa melebihi apa yang diharapkan oleh konsumen sehingga penyedia jasa tersebut menjadi yang terbaik dari penyedia jasa lainnya.

\section{Karakteristik Jasa Perguruan Tinggi}

Menurut Rambat Lupiyoadi terdapat beberapa karakteristik jasa pada lembaga perguruan tinggi adalah sebagai berikut: ${ }^{25}$

Pertama, Perguruan tinggi termasuk dalam kelompok jasa murni di mana pemberian jasa dilakukan atau didukung alat kerja atau sarana pendukung semata. Seperti ruangan kelas, kursi, meja, dan buku-buku.

Kedua, Jasa yang diberikan membutuhkan kehadiran pengguna jasa (mahasiswa), jadi di sini pelanggan yang mendatangi lembaga pendidikan tersebut untuk mendapatkan jasa yang diinginkan.

\footnotetext{
${ }^{22}$ Fredy Rangkuti, Measuring Customer Satisfaction: Gaining Customer Relationship Strategy (Jakarta: Gramedia, 2003), 35.

${ }^{23}$ Rambat Lupiyoadi, Manajemen Pemasaran Jasa: Teori dan Praktik (Jakarta: Salemba Empat, 2003), 143.

${ }^{24}$ Fredy Rangkuti, Measuring Customer Satisfaction: Gaining Customer Relationship Strategy, 35 .

${ }^{25}$ Rambat Lupiyoadi, Manajemen Pemasaran Jasa: Teori Dan Praktik, 126.
} 
Ketiga, Penerima jasa adalah orang, jadi merupakan pemberian jasa yang berbasis orang. Sehingga berdasarkan hubungan dengan pengguna jasa (pelanggan/mahasiswa) adalah high contact sistem yaitu hubungan pemberi jasa dengan pelanggan tinggi. Pelanggan dan pemberi jasa akan selalu berinteraksi selama pemberian jasa berlangsung. Dan untuk menerima jasa tersebut maka pelanggan harus menjadi bagian dari sistem tersebut.

\section{Faktor-Faktor Kepuasan Pelanggan}

Ada berbagai faktor yang memengaruhi kepuasan pelanggan atau pengguna jasa. Untuk itu perlu diketahui faktor-faktor yang memengaruhi kepuasan yang diterima oleh pelanggan atau pengguna jasa. Menurut Moenir yang dialih bahasakan oleh Yulairmi dan Putu R, agar layanan dapat memuaskan orang atau sekelompok orang yang dilayani, ada empat persyaratan pokok, yaitu: 1) tingkah laku yang sopan; 2) cara menyampaikan sesuatu yang berkaitan dengan apa yang seharusnya diterima oleh orang yang bersangkutan; 3) waktu penyampaian yang tepat; dan 4) keramah-tamahan. ${ }^{26}$ Sedangkan menurut Lupiyoadi yang dikutip oleh Delia Halim dalam menentukan tingkat kepuasaan pelanggan terdapat lima faktor utama yang harus diperhatikan, yaitu: ${ }^{27}$

Pertama, Kualitas Produk yaitu Penyedia jasa dalam hal ini adalah perguruan tinggi harus menawarkan kepada pelanggannya sesuatu yang sesuai dengan kebutuhan masiswa agar kepuasan itu akan tercapai. Apabila hasil yang berupa barang atau jasa yang mereka dapatkan sesuai dengan kualitas yang diharapkan maka pelanggan atau mahasiswa sebagai konsumennya akan mengalami kepuasan.

Kedua, Pelayanan. Yaitu pelayanan harus diberikan dengan baik sehingga tercipta kepuasan pada diri pelanggan yang menerima pelayanan tersebut. hal ini juga menjadi faktor yang sangat penting untuk tercapainya kepuasan pelanggan.

Ketiga, Emosional. Seorang mahasiswa yang merasa puas dengan pelayanan di bidang akademik, akan berusaha untuk mempromosikan kepada orang lain untuk memilih produk yang sama dengan dirinya. Karena, pelanggan/pengguna jasa akan merasa bangga apabila mendapat keyakinan dari orang lain dan merasa orang lain merasa kagum dengan dirinya yang menggunakan suatu produk tertentu cenderung memiliki kepuasan yang tinggi. Kepuasan yang diperoleh bukan dari kualitas

\footnotetext{
${ }^{26}$ Yulairmi dan Putu R, Manajemen Pelayanan Umum Di Indonesia. Edisi Kesatu (Jakarta: Bumi Aksara, 2007), 16.

${ }^{27}$ Delia Halim, "Analisis Faktor-Faktor Yang Mempengaruhi Kepuasan Konsumen Restoran Miramar Medan,"(Skripsi SE, Universitas Sumatera Utara, 2006), 23.
} 
produk tetapi nilai sosial atau self-esteem yang membuat pelanggan merasa puas terhadap merek tertentu.

Keempat, Harga. Harga memiliki pengaruh yang besar terhadap kepuasan pelanggan, karena pada dasarnya produk yang memiliki kualitas yang sama tetapi memiliki harga yang realtif murah akan memberikan kepuasan tersendiri bagi pelanggannya.

Kelima, Biaya. Sama halnya dengan harga, biaya juga memiliki peranan penting dalam pemenuhan kepuasan pelanggan. Biaya dan kepuasan pelanggan memiliki hubungan yang bersifat berbanding terbalik, artinya semakin rendah biaya akan semakin tinggi tingkat kepuasan pelanggan dan sebaliknya. Pelanggan yang tidak perlu mengeluarkan biaya tambahan atau tambahan waktu cenderung akan puas terhadap produk yang diberikan.

Selain itu, faktor lain yang berpengaruh terhadap kepuasan pelanggan adalah kepuasan yang berasal dari para petugas yang bekerja di dalam layanan tersebut. Aturan yang berlaku dalam pelaksanaannya, sebab semakin mudah aturannya konsumen atau pelanggan semakin merasa puas. Faktor organisasi yang menjalankan sistem pelayanan juga memiliki pengaruh yang penting terhadap kepuasan pelanggan. Selain itu juga faktor ketersediaan sarana dan prasarana sebagai penunjang layanan untuk memudahkan konsumen dalam mendapatkan produk yang diinginkan. Faktor-faktor yang memengaruhi kepuasan pelanggan adalah kinerja para petugas yang bekerja dalam pelayanan tersebut. Aturan yang diberlakukan dalam pelaksanaannya, sistem yang dimiliki, ketersediaan saran dan prasarana yang dapat memudahkan konsumen untuk mendapat produk yang diinginkan. Menurut Philip Kotler dalam Supranto dapat dispesifikkan dari teori jasa, pelayanan dan kepuasan pelanggan maka dihasilkan faktor yang memengaruhi kepuasan pelanggan adalah: ${ }^{28}$

a. Faktor keandalan (reliability)

Keandalan adalah kemampuan penyedia layanan untuk melaksanakan jasa yang dijanjikan dengan konsisten dan terpercaya. Kepuasan akan terpenuhi apabila jasa yang ditawarkan kepada pelanggan sesuai dengan yang dijanjikan.

b. Faktor ketanggapan (responsiveness)

Ketanggapan adalah kemauan untuk membantu pelanggan dan memberikan jasa dengan cepat atau tanggap. Ketanggapan akan memberikan pengaruh yang baik terhadap kepuasan pelanggan, karena ketika suatu perusahaan mampu memberikan tanggapan yang baik

${ }^{28}$ J. Supranto, Pengukuran Tingkat Kepuasan Pelanggan (Jakarta: Rineka Cipta, 2006), 
kepada konsumennya maka akan menambah nilai tersendiri bagi perusahan di mata pelanggannya.

c. Faktor keyakinan (confidence)

Keyakinan adalah pengetahuan dan kesopanan karyawan serta kemampuan mereka untuk menimbulkan kepercayaan dan keyakinan atau "assurance". Jadi, pelanggan akan mengalami kepuasan apabila ada jaminan yang mampu diberikan oleh penyedia jasa terhadap kualitas layanan yang diberikan kepada pelanggan serta adanya rasa aman yang dialami oleh pelanggan terhadap barang-barang yang dibawanya.

d. Faktor empati (emphaty)

Empati adalah adanya rasa peduli, pemberian perhatian pribadi bagi pelanggan. Hal ini sangat penting karena kepuasan pelanggan juga akan tercapai apabila timbul rasa nyaman yang dialami oleh pelanggan dalam menggunakan jasa pelayanan yang diberikan.

e. Faktor berwujud (tangible)

Berwujud adalah penampilan fasilitas fisik, peralatan, personel dan media komunikasi. Faktor ini juga akan memberikan pengaruh yang positif terhadap kepuasaan pelanggan, karena semakin baik kualitas dari fasilitas yang digunakan dalam pemberian jasa akan semakin baik pula tingkat kepuasan pelanggan.

Dalam buku karangan Patricia Patton yang berjudul EQ Pelayanan Sepenuh Hati, faktor kepuasan pelanggan dapat dilihat dari terpenuhinya lima komponen layanan sepenuh hati yaitu: memahami emosi-emosi kita, kompetensi, mengelola emosi-emosi kita, bersikap kreatif dan memotivasi diri sendiri, menyelaraskan emosi-emosi orang lain. ${ }^{29}$

Arah penelitian ini untuk mengetahui faktor yang memengaruhi kepuasan mahasiswa dalam menggunakan jasa pelayanan akademik maka, teori-teori tersebut dapat diterapkan, namun untuk melihat tingkat kepuasan mahasiswa sebagai konsumennya maka teori Kotler lebih tepat.

\section{Hasil Penelitian}

Penelitian ini dilakukan di STT Jaffray Makassar dengan bertindak sebagai responden adalah mahasiswa STT Jaffray angkatan 2012-2015 yang berjumlah 46 mahasiswa yang tersebar di 4 angkatan. Dari hasil penelitian ini dimaksud untuk mengetahui tingkat kepuasan mahasiswa terhadap pelayanan akademik STT Jaffray Makassar. Dari gambaran ini dapat diketahui seberapa besar data kepuasan mahasiswa terhadap pelayanan akademik STFT Jaffray Makassar.

\footnotetext{
${ }^{29}$ Patricia Patton, EQ Pelayanan Sepenuh Hati, Meraih EQ untuk Pelayanan yang Memuaskan Pelanggan (Jakarta: Pustaka Delapratasa, 2000), 12-21.
} 
Data untuk mengetahui tingkat kepuasan mahasiswa terhadap pelayanan akademik STT Jaffray Makassar terdiri atas 2 bentuk penelitian. Penelitian pertama tentang pelayanan akdemik yang terdiri 39 pernyataan, yang dibagi menjadi 6 faktor, yaitu tangible 8 pernyataan, reliability 9 pernyataan, Responsiveness 5 pernyataan, Assurance 5 pernyataan, empathy 6 pernyataan, aspek sistem informasi 6 pernyataan.

Tabel 1. Profil Subjek Angket

\begin{tabular}{|c|c|c|c|c|}
\hline No & Kategori & $\begin{array}{c}\text { Jumlah } \\
\text { Responden }\end{array}$ & $\begin{array}{c}\text { Jumlah responden } \\
\text { yang } \\
\text { mengembalikan }\end{array}$ & $\begin{array}{c}\text { Jumlah } \\
\text { responden yang } \\
\text { tidak } \\
\text { mengembalikan }\end{array}$ \\
\hline 1 & Angkatan 2015 & 9 & 9 & - \\
\hline 2 & Angkatan 2014 & 10 & 10 & - \\
\hline 3 & Angkatan 2013 & 12 & 12 & - \\
\hline 4 & Angkatan 2012 & 15 & 15 & 46 \\
\hline \multicolumn{5}{|c}{ Jumlah } \\
\hline
\end{tabular}

\section{Analisis Hasil Penelitian}

Parameter Tangible ditujukan pada fasilitas fisik, peralatan, personel dan media komunikasi yang dapat memengaruhi kepuasan pelanggan. Pernyataan 1 tentang ruang kuliah. Ada sebanyak 3 (6,52\%) mahasiswa yang menjawab tidak puas keadaan ruang kuliah yang ada saat ini dan 4 $(8,69 \%)$ mahasiswa menjawab kurang memuaskan karena menurut mereka sebenarnya ruang kuliah tidak tertata dengan rapi dan bersih, sebanyak 12 (26,08\%) mahasiswa yang menjawab cukup memuaskan dengan kondisi ruang kuliah yang tertata rapi dan bersih, sebanyak 19 (41,30\%) mahasiswa yang menjawab bahwa ruang kuliah tertata bersih dan rapi, dan sebanyak 8 (17,39\%) mahasiswa yang menjawab dengan sangat memuaskan bahwa ruang kuliah tertata rapi dan bersih.

Penyataan 2 tentang ruang kuliah terasa nyaman dan sejuk. Ada sebanyak 12 (26,08\%) mahasiswa menjawab kurang memuaskan artinya mereka menyatakan ruang kuliah belum nyaman, sebanyak 20 (43,47\%) mahasiswa yang menjawab bahwa ruang kuliah sebenarnya cukup memuaskan dan terasa nyaman, sebanyak 11 (23,9l\%) mahasiswa menyatakan puas bahwa ruang kuliah sebenarnya terasa nyaman dan sejuk, sebanyak $3(23,91 \%)$ mahasiswa menjawab dengan sangat memuaskan bahwa ruang kuliah terasa sejuk dan nyaman.

Pernyataan 3 tentang sarana pembelajaran. Dari pernyattaan itu ada mahasiswa sebanyak 17 (36,95\%) mahasiswa yang merasa kurang puas dengan sarana pembelajaran yang ada di ruang kuliah, sebanyak 20 $(43,95 \%)$ mahasiswa yang menjawab cukup puas dengan sarana pembelajaran yang tersedia di ruang kuliah, sebanyak 8 (17,39\%) 
mahasiswa yang menjawab bahwa sarana pembelajaran dalam ruang kuliah memuaskan, dan $1(2,17 \%)$ mahasiswa yang menjawab sarana pembelajaran dalam ruang kuliah sangat memuaskan.

Pernyataan 4 tentang fasilitas perpustakaan. Sebanyak 18 (39,13\%) mahasiswa yang menjawab cukup memuaskan bahwa STT Jaffray memiliki perpustakaan yang lengkap, sebanyak 22 (47,82\%) mahasiswa yang menjawab cukup memuaskan tentang kelengkapan perpustakaan STT Jaffray Makassar, dan sebanyak 6 (13,04\%) mahasiswa yang menjawab dengan sangat memuaskan tentang kelengkapan perpustakaan di STT Jaffray Makassar.

Pernyataan 5 tentang fasilitas laboratorium. Ada sebanyak 17 $(36,95 \%)$ mahasiswa yang menjawab cukup memuaskan dengan adanya laboratorium yang sesuai dengan kebutuhan mahasiswa, sebanyak 23 (50\%) mahasiswa yang menjawab dengan memuaskan tentang adanya laboratorium yang sesuai dengan kebutuhan mahasiswa, dan sebanyak 6 $(13,04 \%)$ mahasiswa yang menjawab dengan sangat memuaskan tentang laboratorium yang sesuai dengan kebutuhan mahasiswa.

Pernyataan 6 mengenai kelengkapan buku referensi, ada sebanyak sebanyak $3(6.52 \%)$ mahasiswa yang menjawab kurang memuaskan tentang kelengkapan buku referensi di perpustakaan, sebanyak 12 $(26,08 \%)$ mahasiswa yang menjawab cukup memuaskan dengan kelengkapan buku-buku referensi di perpustakaan, sebanyak 23 (50\%) mahasiswa yang menjawab dengan memuaskan tentang kelengkapan buku-buku referensi di perpustakaan, dan sebanyak 8 (17,39\%) mahasiswa yang menjawab dengan sangat memuaskan tentang kelengkapan buku-buku referensi di perpustakaan.

Pernyataan 7 tentang fasilitas kamar kecil (WC), ada sebanyak 19 $(41,34 \%)$ mahasiswa yang menjawab cukup memuaskan dengan ketersediaan kamar kecil di STT Jaffray, sebanyak 19 (41,34\%) mahasiswa yang menjawab dengan memuaskan tentang ketersediaan kamar kecil di STT Jaffray, dan sebanyak 3 (6,52\%) mahasiswa yang menjawab dengan sangat memuaskan tentang ketersediaan kamar kecil yang bersih di STT Jaffray.

Pernyataan 8 tentang fasilitas ibadah. Ada sebanyak 3 (6,52\%) mahasiswa yang menjawab cukup memuaskan dengan adanya fasilitas ibadah yang bisa digunakan oleh mahasiswa di STT Jaffray Makassar, sebanyak 18 (39,13\%) mahasiswa yang menjawab dengan memuaskan tentang adanya fasilitas ibadah yang bisa digunakan oleh mahasiswa di STT Jaffray Makassar, dan sebanyak 25 (54,34\%) mahasiswa yang menjawab dengan sangat memuaskan tentang fasilitas ibadah di STT Jaffray Makassar.

Dengan demikian dapat disimpulkan bahwa kepuasan mahasiswa terhadap fasilitas fisik yang ada di kampus STT Jaffray berdasarkan 46 
responden dengan 8 pernyataan yang telah dijawab maka hasilnya $71,19 \%$. Artinya kepuasan mahasiswa mendekati memuaskan. Oleh karena itu, ruangan kuliah yang nyaman dan sejuk serta sarana pembelajaran perlu ditingkatkan supaya kepuasan mahasiswa dapat mendekati sangat memuaskan.

Pernyataan 1 , ada sebanyak 2 (4,34\%) mahasiswa yang menjawab bahwa mereka kurang puas tentang kejelasan materi perkuliahan yang diberikan oleh dosen, dan 18 (39,13\%) mahasiswa menjawab cukup memuaskan tentang kejelasan materi perkuliahan yang diberikan oleh dosen, sebanyak 18 (13,91\%) mahasiswa yang menjawab memuaskan dengan tentang kejelasan materi perkuliahan yang diberikan oleh dosen, dan sebanyak 8 (17,39\%) mahasiswa yang menjawab dengan sangat memuaskan tentang kejelasan materi perkuliahan yang diberikan oleh dosen.

Kepuasan akan terpenuhi apabila jasa yang ditawarkan kepada pelanggan sesuai dengan yang dijanjikan (reliability). Reliability pelayanan staf pengajar dan staf akademik dalam mendukung proses belajar mengajar dan evaluasi pembelajaran. Pernyataan 1 tentang kejelasan materi perkuliahan. Ada sebanyak 2 (4,34\%) mahasiswa yang menjawab bahwa mereka kurang puas tentang kejelasan materi perkuliahan yang diberikan oleh dosen, dan 18 (39,13\%) mahasiswa menjawab cukup memuaskan tentang kejelasan materi perkuliahan yang diberikan oleh dosen, sebanyak 18 (13,91\%) mahasiswa yang menjawab memuaskan dengan tentang kejelasan materi perkuliahan yang diberikan oleh dosen, dan sebanyak 8 (17,39\%) mahasiswa yang menjawab dengan sangat memuaskan tentang kejelasan materi perkuliahan yang diberikan oleh dosen.

Pernyataan 2 tentang adanya waktu diskusi dan tanya jawab. Ada sebanyak $15(32,60 \%)$ mahasiswa menjawab kurang puas tentang adanya waktu untuk diskusi dan tanya jawab. Sebanyak 12 (26,08\%) mahasiswa yang menjawab dengan cukup memuaskan adanya waktu untuk diskusi dan tanya jawab, sebanyak 12 (26,08\%) menjawab dengan memuaskan tentang adanya waktu untuk diskusi dan tanya jawab, sebanyak 7 $(15,21 \%)$ mahasiswa menjawab dengan sangat memuaskan adanya waktu untuk diskusi dan tanya jawab.

Pernyataan 3 tentang bahan ajar suplemen. Ada sebanyak 3 (6,52\%) mahasiswa yang merasa kurang puas bahan ajar suplemen yang diberikan kepada mahasiswa, sebanyak 17 (36,95\%) mahasiswa yang menjawab cukup puas terhadap bahan ajar suplemen yang diberikan kepada mahasiswa, sebanyak 18 (39,13\%) mahasiswa yang menjawab dengan memuaskan tentang bahan ajar suplemen yang diberikan kepada mahasiswa, dan sebanyak 8 (17,39\%) mahasiswa yang merasa sangat 
memuaskan tentang bahan ajar suplemen yang diberikan kepada mahasiswa.

Pernyataan 4 tentang pengembalian tugas dan penilaian objektif dosen.Ada sebanyak 3 (6,52\%) mahasiswa yang merasa kurang puas dengan pengembalian tugas dan penilaian yang objektif dari dosen, sebanyak 17 (36,95\%) mahasiswa yang menjawab cukup puas tentang pengembalian tugas dan penilaian yang objektif dari dosen, sebanyak 18 $(39,13 \%)$ mahasiswa yang menjawab dengan memuaskan tentang pengembalian tugas dan penilaian yang objektif dari dosen, dan sebanyak $8(17,39 \%)$ mahasiswa yang merasa sangat puas tentang pengembalian tugas dan penilaian yang objektif dari dosen.

Pernyataan 5, ada sebanyak 11 (23,91\%) mahasiswa yang menjawab kurang memuaskan tentang dosen yang tidak tepat waktu, sebanyak 19 $(41,30 \%)$ mahasiswa yang menjawab cukup memuaskan tentang dosen yang datang tepat waktu, dan sebanyak $13(28,26 \%)$ mahasiswa yang menjawab dengan memuaskan tentang kedatangan dosen yang tepat waktu, dan ada sebanyak 3 (6,52\%) mahasiswa yang menjawab dengan sangat memuaskan tentang kedatangan dosen yang tepat waktu.

Pernyataan 6 tentang keahlian dosen. Ada sebanyak 8 (17,39\%) mahasiswa yang menjawab kurang memuaskan tentang dosen yang memadai sesuai keahliannya $15(32,60 \%)$ mahasiswa yang menjawab cukup memuaskan tentang dosen yang memadai sesuai keahliannya, dan sebanyak 9 (19,56\%) mahasiswa yang menjawab dengan memuaskan tentang dosen yang memadai sesuai keahliannya, dan sebanyak 14 $(30,43 \%)$ mahasiswa yang menjawab dengan sangat memuaskan tentang dosen yang memadai sesuai keahliannya.

Pernyataan 7 tentang Satuan Acara Perkuliahan. Ada sebanyak 4 $(8,69 \%)$ mahasiswa yang menjawab cukup memuaskan dengan satuan acara perkuliahan yang dibuat oleh dosen, sebanyak 9 (19,56\%) mahasiswa yang menjawab dengan memuaskan tentang dengan satuan acara perkuliahan yang dibuat oleh dosen, dan sebanyak 33 (71,73\%) mahasiswa yang menjawab dengan sangat memuaskan dengan satuan acara perkuliahan yang dibuat oleh dosen.

Pernyataan 8 tentang satuan alat perkuliahan. Ada sebanyak 4 $(8,69 \%)$ mahasiswa yang menjawab cukup memuaskan tentang satuan alat perkuliahan yang dibuat oleh dosen, sebanyak $9 \quad(14,56 \%)$ mahasiswa yang menjawab dengan memuaskan tentang satuan alat perkuliahan yang dibuat oleh dosen, dan sebanyak 33 (71,73\%) mahasiswa yang menjawab dengan sangat memuaskan tentang satuan alat perkuliahan yang dibuat oleh dosen.

Pernyataan 9 tentang kualitas staf akademik untuk memenuhi kepentingan mahasiswa. Ada sebanyak 6 (13,04\%) mahasiswa yang menjawab dengan kurang puas terhadap kualitas staf akademik untuk 
memenuhi kepentingan mahasiswa, dan sebanyak 20 (43,47\%) mahasiswa yang menjawab dengan cukup puas terhadap kualitas staf akademik untuk memenuhi kepentingan mahasiswa, sebanyak 14 $(30,43 \%)$ mahasiswa yang menjawab dengan memuaskan terhadap kualitas staf akademik untuk memenuhi kepentingan mahasiswa, sebanyak $6(13,04 \%)$ mahasiswa yang menjawab dengan memuaskan terhadap kualitas staf akademik untuk memenuhi kepentingan mahasiswa. Melalui perhitungan Rating Scale diperoleh bahwa 71,73\% atau menunjukkan bahwa responden memberikan nilai reliability yang mendekati memuaskan.

Pada bagian ini Responsiveness (Sikap Tanggap) pelayanan dosen dan akademik terhadap kepuasan mahasiswa. Pernyataan 1 tentang bimbingan konseling dari dosen konseling. Ada sebanyak 3 (6,52\%) mahasiswa yang menjawab bahwa mereka tidak puas karena tidak pernah mendapat bimbingan konseling dari dosen konseling, dan sebanyak 6 (13,04\%) mahasiswa menjawab kurang memuaskan karena jarang mendapatkan konseling ketika mengalami masalah, dan sebanyak $22(47,82 \%)$ mahasiswa menjawab cukup memuaskan dengan adanya dosen bimbingan konseling, sebanyak 15 (32,60\%) mahasiswa yang menjawab dengan memuaskan tentang adanya dosen bimbingan konseling dari STT Jaffray.

Pernyataan 2 tentang beasiswa bagi mahasiswa yang kurang mampu. Ada sebanyak 3 (6,52\%) mahasiswa menjawab dengan tidak memuaskan tentang beasiswa bagi mahasiswa yang kurang mampu, sebanyak 1 (2,17\%) mahasiswa yang menjawab dengan kurang memuaskan tentang beasiswa bagi mahasiswa yang kurang mampu, sebanyak 14 (30,43\%) menjawab dengan cukup memuaskan tentang adanya beasiswa yang selama ini berlaku di STT Jaffray, sebanyak 24 $(52,17 \%)$ mahasiswa menjawab dengan memuaskan tentang beasiswa bagi mahasiswa yang kurang mampu, dan sebanyak 4 (8,69\%) mahasiswa menjawab dengan memuaskan tentang beasiswa bagi mahasiswa yang kurang mampu.

Pernyataan 3 tentang bantuan pihak STT Jaffray kepada mahasiswa. Ada sebanyak 1 (2,17\%) mahasiswa yang merasa tidak puas karena tidak mendapat bantuan dari pihak kampus STT Jaffray Makassar apabila menghadapi masalah akademik, sebanyak 12 (26,08\%) mahasiswa yang menjawab kurang memuaskan karena jarang mendapat bantuan dari pihak kampus STT Jaffray Makassar apabila menghadapi masalah akademik, sebanyak 15 (32,60\%) mahasiswa yang menjawab dengan cukup memuaskan tentang adanya bantuan yang diberikan oleh STT Jaffray bila ada mahasiswa yang bermasalah dalam bidang akademik, dan sebanyak 18 (39,13\%) mahasiswa yang merasa puas terhadap bantuan yang diberikan oleh kepada akademik STT Jaffray. 
Pernyataan 4, ada sebanyak 6 (13,04\%) mahasiswa yang merasa tidak puas Pimpinan STT Jaffray Makassar beserta jajarannya selama ini jarang menyediakan waktu bagi orang tua mahasiswa untuk berkonsultasi, sebanyak 6 (13,04\%) mahasiswa yang menjawab kurang memuaskan tentang Pimpinan STT Jaffray Makassar beserta jajarannya menyediakan waktu bagi orang tua mahasiswa untuk berkonsultasi, sebanyak 22 (47,82\%) mahasiswa yang menjawab dengan cukup memuaskan tentang Pimpinan STT Jaffray Makassar beserta jajarannya menyediakan waktu bagi orang tua mahasiswa untuk berkonsultasi, dan sebanyak $3(6,52 \%)$ mahasiswa yang merasa sangat puas tentang Pimpinan STT Jaffray Makassar beserta jajarannya menyediakan waktu bagi orang tua mahasiswa untuk berkonsultasi.

Pernyataan 5 tentang dosen yang tidak tepat waktu. Ada sebanyak ll $(23,91 \%)$, mahasiswa yang menjawab kurang memuaskan tentang dosen yang tidak tepat waktu, sebanyak 19 (41,30\%) mahasiswa yang menjawab cukup memuaskan tentang dosen yang datang tepat waktu, dan sebanyak $13 \quad(28,26 \%)$ mahasiswa yang menjawab dengan memuaskan tentang kedatangan dosen yang tepat waktu, dan sebanyak 3 (6,52\%) mahasiswa yang menjawab dengan sangat memuaskan tentang Pimpinan STT Jaffray Makassar beserta jajarannya menyediakan waktu bagi orang tua mahasiswa untuk berkonsultasi.

Hasil rating scale menunjukkan $64,17 \%$ yang berarti responden menjawab 5 pernyataan di atas adalah cukup memuaskan. Hal ini perlu ditingkatkan terutama memerhatikan mahasiswa dengan pelayanan konseling dan memahami permasalahan mahasiswa terutama dalam pembiayaan kuliah.

Pernyataan Assurance (Perlakuan Pada Mahasiswa) yang dilakukan oleh staf akademik yang memengaruhi tingkat kepuasan mahasiswa. Pernyataan 1 tentang staf akademik berlaku santun dalam melayani mahasiswa. Ada sebanyak 4 (8,69\%) mahasiswa yang menjawab bahwa mereka tidak puas karena terhadap administrasi akademik yang berlaku tidak santun dalam melayani, sebanyak 11 (23,91\%) mahasiswa menjawab kurang memuaskan tidak mendapat perlakuan santun dari bidang administrasi, sebanyak 21 (45,65\%) mahasiswa menjawab cukup memuaskan perlakuan dari staf administrasi dalam memberikan pelayanan, sebanyak 8 (17,39\%) mahasiswa yang menjawab dengan memuaskan tentang adanya sikap yang ditunjukkan oleh staf akademik dalam memberikan pelayanan. Dan sebanyak 2 (4,34\%) mahasiswa memberikan jawaban sangat memuaskan terhadap pelayanan dari staf administrasi akademik.

Pernyataan 2 tentang keluhan mahasiswa yang dilayani oleh dosen pembimbing. Ada sebanyak 6 (13,04\%) mahasiswa menjawab dengan tidak memuaskan tentang permasalahan yang mereka hadapi yang 
ditangani oleh dosen pembimbing, sebanyak 6 (13,04\%) mahasiswa yang menjawab dengan kurang memuaskan tentang peranan dosen pembimbing akademik dalam mendengar permasalahan mereka, sebanyak 21 (45,65\%) menjawab dengan cukup memuaskan tentang permasalahan yang mereka hadapi selalu ditangani dengan baik oleh dosen pembimbing akademik, sebanyak 13 (28,26\%) mahasiswa menjawab dengan memuaskan setiap masalah yang berhubungan dengan akademik mampu diselesaikan dengan baik oleh pembimbing akademik.

Pernyataan 3 tentang tugas yang dikembalikan kepada mahasiswa. ada $16(34,78 \%)$ mahasiswa yang menjawab cukup memuaskan tentang tugas yang dikembalikan kepada mahasiswa dan sebanyak 18 (39,13\%) mahasiswa menjawab memuaskan tentang tugas yang dikembalikan kepada mahasiswa. Dan sebanyak 12 (26,08\%) mahasiswa menjawab sangat memuaskan tugas yang dikembalikan kepada mahasiswa.

Pernyataan 4, ada sebanyak 1 (2,17\%) mahasiswa menjawab tidak memuaskan tentang dosen yang tidak efektif dalam menggunakan waktu didalam pengajarannya, sebanyak 6 (13,04\%) mahasiswa yang menjawab kurang memuaskan tentang penggunaan waktu dari dosen yang tidak efektif dalam pengajarannya, sebanyak $18 \quad(39,14 \%)$ mahasiswa yang menjawab dengan cukup memuaskan tentang dosen penggunaan waktu yang efektif dari dosen dalam pengajarannya, dan sebanyak 19 (41,30\%) mahasiswa menjawab memuaskan tentang dosen penggunaan waktu yang efektif dari dosen dalam pengajarannya. Dan sebanyak 2 (4,34\%) Mahasiswa menjawab sangat memuaskan tentang dosen yang menggunakan waktu dengan efektif dalam pengajarannya.

Pernyataan 5 tentang sanksi yang diberikan STT Jaffray kepada mahasiswa. Ada sebanyak 22 (47,82\%) mahasiswa yang menjawab cukup memuaskan tentang sanksi yang diberikan STT Jaffray dalam mendisiplinkan mahasiswanya, sebanyak 22 (47,82\%) mahasiswa yang menjawab memuaskan tentang disiplin mahasiswa yang diberikan tanpa memandang buluh, dan sebanyak 2 (4,34\%) mahasiswa yang menjawab dengan sangat memuaskan tentang Sanksi bagi mahasiswa yang melanggar peraturan yang telah ditetapkan STT Jaffray Makassar dan berlaku untuk semua mahasiswa tanpa terkecuali.

Pernyataan tentang Empathy (pemahaman terhadap kepentingan mahasiswa) yang dapat berpengaruh kepada kepuasan mahasiswa. Pernyataan 1 tentang memahami minat dan bakat mahasiswa. Ada sebanyak l (2,17\%) mahasiswa yang menjawab bahwa mereka tidak puas karena merasa minat dan bakatnya tidak diasah oleh STT Jaffray, sebanyak $5(10,86 \%)$ mahasiswa menjawab kurang memuaskan karena merasa pihak STT Jaffray tidak memahami minat dan bakatnya, sebanyak 31 (67,39\%) mahasiswa menjawab cukup memuaskan karena merasa minat dan bakat mereka diperhatikan, sebanyak 8 (17,39\%) 
mahasiswa yang menjawab dengan memuaskan tentang minat dan bakat mereka diperhatikan. Dan sebanyak 1 (2,17\%) mahasiswa memberikan jawaban sangat memuaskan perhatian minat dan bakat dari STT Jaffray.

Pernyataan 2 tentang monitoring bimbingan mahasiswa. Ada sebanyak 7 (15,21\%) mahasiswa menjawab dengan kurang memuaskan karena merasa kinerja dosen pembimbing dalam memonitor setiap mahasiswa bimbingannya, sebanyak 16 (34,78\%) mahasiswa yang menjawab dengan cukup memuaskan tentang peranan dosen pembimbing akademik dalam mengontrol kemajuan mahasiswanya, sebanyak 23 (50\%) menjawab dengan memuaskan tentang permasalahan yang mereka hadapi selalu ditangani dengan baik oleh dosen pembimbing akademik.

Pernyataan 3 tentang ketersediaan dosen dalam membantu bidang akademik mahasiswa. Ada sebanyak 2 (4,34\%) mahasiswa menjawab kurang memuaskan terhadap ketersediaan dosen dalam menolong mahasiswa yang mengalami masalah akademik, sebanyak 5 (10,86\%) mahasiswa yang menjawab cukup memuaskan tentang pertolongan dosen dalam menolong mahasiswanya ketika mengalami kesulitan di bidang akademik, sebanyak 32 (69,56\%) mahasiswa yang menjawab dengan memuaskan tentang keterlibatan dosen dalam menolong mahasiswa yang mengalami masalah dalam kuliah dan bidang akademik, dan sebanyak $7(15,21 \%)$ mahasiswa menjawab sangat memuaskan tentang keterlibatan dosen dalam membimbing mahasiswa yang bermasalah dalam bidang akademik.

Pernyataan 4 tentang keterbukaan dosen terhadap mahasiswa, ada sebanyak 3 (6,52\%) mahasiswa menjawab dengan kurang memuaskan karena masih ada dosen yang belum bersikap terbuka kepada mahasiswa, sebanyak 21 (45,65\%) mahasiswa yang menjawab dengan cukup memuaskan tentang sikap dosen yang terbuka dan kooperatif dan terbuka dengan mahasiswa, sebanyak 16 (34,78\%) menjawab dengan memuaskan tentang sikap dosen yang terbuka dan kooperatif dengan mahasiswa. Dan sebanyak $6(13,04 \%)$ menjawab dengan memuaskan tentang sikap dosen yang terbuka dan kooperatif dengan mahasiswa.

Pernyataan 5 tentang pemantauan minat dan bakat mahasiswa. Ada sebanyak 2 (4,43\%) mahasiswa yang menjawab kurang memuaskan tentang sikap STT Jaffray dalam memahami minat dan bakat mahasiswanya, sebanyak 19 (41,30\%) mahasiswa yang menjawab cukup memuaskan karena merasa minat dan bakatnya dipantau oleh STT Jaffray dan terus dikembangkan, dan sebanyak 25 (54,34\%) mahasiswa yang menjawab dengan memuaskan karena merasa bakatnya terus dikembangkan dan dipakai di STT Jaffray.

Aspek informasi akademik mahasiswa dapat memengaruhi kepuasan mahasiswa. Pernyataan 1 tentang buku panduan perkuliahan. 
Ada sebanyak 19 (41,30\%) mahasiswa yang menjawab dengan cukup memuaskan STT Jaffray memberikan informasi sistem perkuliahan dalam bentuk buku panduan perkuliahan, sebanyak 20 (10,86\%) mahasiswa menjawab memuaskan karena STT Jaffray memberikan informasi sistem perkuliahan dalam bentuk buku panduan perkuliahan, dan sebanyak 7 (15,21\%) mahasiswa menjawab sangat memuaskan karena STT Jaffray memberikan informasi sistem perkuliahan dalam bentuk buku panduan perkuliahan.

Pernyatan 2 tentang informasi akademik lewat website. Ada sebanyak 9 (19,56\%) mahasiswa menjawab dengan cukup memuaskan karena bisa mengetahui informasi akademik dan non akademik lewat website, sebanyak $12(34,78 \%)$ mahasiswa yang menjawab dengan memuaskan tentang informasi akademik dan non akademik dalam bentuk website, dan sebanyak 25 (54,34\%) menjawab dengan sangat memuaskan tentang informasi akademik yang bisa diakses dengan mudah dalam bentuk website.

Pernyataan 3 tentang pemberian informasi akademik. Ada sebanyak l (2,17\%) mahasiswa menjawab kurang memuaskan terhadap STT Jaffray secara terbuka memberikan informasi dan pelayanan baik akademik maupun non akademik, sebanyak 19 (41,30\%) STT Jaffray secara terbuka memberikan informasi dan pelayanan baik akademik maupun non akademik, sebanyak 25 (54,34\%) STT Jaffray secara terbuka memberikan informasi dan pelayanan baik akademik maupun non akademik, dan sebanyak 1 (2,17\%) mahasiswa menjawab sangat memuaskan tentang STT Jaffray secara terbuka memberikan informasi dan pelayanan baik akademik maupun non akademik.

Pertanyaan 4 tentang sistem pengaduan mahasiswa. Ada sebanyak $19(41,30 \%)$ mahasiswa menjawab kurang memuaskan karena merasa yakin jika sistem pengaduan bagi mahasiswa tidak berlaku lagi, sebanyak 19 (41,30\%) mahasiswa yang menjawab dengan cukup memuaskan tentang layanan pengaduan bagi mahasiswa yang memiliki permasalahan, sebanyak $5(10,86 \%)$ mahasiswa menjawab dengan memuaskan tentang STT Jaffray membuka layanan pengaduan bagi mahasiswa yang memiliki permasalahan. Dan sebanyak 3 (6,52\%) mahasiswa menjawab dengan sangat memuaskan tentang sikap dosen yang terbuka STT Jaffray membuka layanan pengaduan bagi mahasiswa yang memiliki permasalahan.

Pernyataan 6 tentang penggunaan dana kemahasiswaan. Ada sebanyak 8 (17,39\%) mahasiswa yang menjawab tidak memuaskan karena merasa tidak ada transparansi tentang penggunaan dana kemahasiswaan, sebanyak 14 (30,43\%) mahasiswa yang menjawab kurang memuaskan karena merasa tidak ada transparansi tentang penggunaan dana kemahasiswaan, dan sebanyak 17 (36,95\%) mahasiswa 
yang menjawab dengan cukup memuaskan karena merasa penggunaan dana kemahasiswaan sudah transparansi sejak awal pembayaran. Dan sebanyak $7(15,21 \%)$ mahasiswa yang menjawab dengan memuaskan karena yakin bahwa tentang penggunaan dana kemahasiswaan sudah sesuai prosedurnya.

\section{Kesimpulan Analisis}

Dari hasil angket tertutup yang disebarkan kepada mahasiswa STT Jaffray Makassar yang telah dianalisis maka penulis menyimpulkan beberapa hal.

Pertama, mengenai sarana pendidikan di STT Jaffray Makassar maka disimpulkan bahwa kebutuhan mengenai sarana pendidikan masih perlu ditingkatkan. Dengan masih adanya ketidakpuasan sarana pendidikan terutama di dalam kelas. Namun banyak mahasiswa yang mengatakan bahwa pihak kampus sebagai penyedia jasa sudah melakukan yang terbaik dalam pelayanan kepada mahasiswa sebagai konsumennya.

Kedua, mengenai reliability atau kehandalan dosen dan staf akademik, dari hasil beberapa mahasiswa mengakui bahwa staf maupun dosen yang dimiliki oleh kampus sebagai penyedia jasa sesuai kapasitas.

Ketiga, responsiveness atau sikap tanggap ini sebenarnya sudah sangat baik yang diberikan oleh bidang akademik selama ini. Dari hasil angket di atas kita bisa melihat selalu lebih dari 30\% mahasiswa menjawab dengan cukup memuaskan dari setiap pertanyaan terhadap respons yang diberikan oleh pihak akademik kepada mahasiswa ketika mengalami kendala. Akademik telah menyediakan dosen pembimbing sekaligus menjadi dosen konseling bagi mahasiswa yang mengalami masalah akademik atau masalah lainnya.

Keempat, assurance atau perlakuan kepada mahasiswa selama ini sangat baik. Perlakuan yang diberikan akademik selama ini sudah cukup memuaskan. Setiap tugas-tugas yang dikumpulkan oleh mahasiswa selalu dikembalikan kepada mahasiwa. Setiap permasalahan atau keluhan yang disampaikan kepada pembimbing akademik selalu ditangani dengan baik. Berhubungan teori Maslow tentang penghargaan hubungannya denga perlakuan kepada mahasiswa, selama ini bidang akademik selalu memberikan penghargaan kepada mahasiswa bagi mereka yang berprestasi dalam bidang akademik.

Kelima, empathy atau pemahaman kepentingan mahasiswa. Selama ini bidang akademik memahami kepentingan dan kesulitan mahasiswa. Untuk itu bidang akademik memberikan tanggung jawab kepada dosen pembimbing untuk memonitor perkembangan mahasiswa yang mengalami kesulitan di bidang akademik. Dosen-dosen selalu bersikap terbuka dengan mahasiswa. 
Keenam, sistem informasi kemahasiswaan. Untuk sistem informasi STFT Jaffray sebagai penyedia jasa telah membuka sistem berbasis website. Baik itu tentang perkuliahan, maupun kegiatan akademik lainnya. STFT Jaffray telah mempunyai website sendiri yang memudahkan mahasiswa untuk mengakses atau mencari informasi sendiri yang berkaitan dengan bidang akademik.

\section{Kepustakaan}

Abdul-Muhmin, Alhassan G. "Effects of Suppliers' Marketing Program Variables on Industrial Buyers Relationship Satisfaction and Commitment." Journal of Business and Industrial Marketing 17, No. 7 (2002):637-649.

Band, William A. Creating value for customer: Designing and Implementation a Total Corporate Strategy. John Walley and Sons Inc, Canada, 1991.

Biong, H. "Satisfaction and Loyalty to Suppliers Within Grocery Trade."

European Journal of Marketing 27/7 (1993):21-38.

Gaspersz, V. Penerapan Konsep VINCENT Tentang Kualitas Dalam Manajemen

Bisnis Total. Jakarta: Yayasan Indonesia Emas dan Gramedia, 2002.

Gaspersz, V.Total Quality Management.Jakarta: Gramedia, 2008.

Halim, D. "Analisis Faktor-Faktor Yang Mempengaruhi Kepuasan Konsumen Restoran Miramar Medan." Skripsi SE. Universitas Sumatera Utara, 2006.

Iswani, A. dan T. S. Yanti. "Analisis Faktor-Faktor Kepuasan Mahasiswa

Terhadap Pelayanan Universitas Islam Bandung sebagai Institusi

Pendidikan Tinggi." Makalah yang dipresentasikan pada Prosiding untuk Universitas Islam Bandung, 2011.

Kotler, P. dan Gary Armstrong. Prinsip-Prinsip Pemasaran Edisi 12. Jakarta: Erlangga, 2008.

Lupiyoadi, R. Manajemen Pemasaran Jasa: Teori dan Praktik. Jakarta: Salemba Empat, 2003.

Muhaimin, Manajemen Pendidikan Aplikasinya Dalam Penyusunan Rencana Pengembangan Sekolah/Madrasah. Jakarta: Kencana, $2010 .$.

Musanto, T. "Faktor-Faktor Kepuasan Pelanggan dan Loyalitas Pelanggan: Studi Kasus pada CV. Sarana Media Advertising Surabaya." Jurnal Manajemen e Kewirausahaan 6, no. 2 (September 2004): 123-136.

Patton, P. EQ Pelayanan Sepenuh Hati, Meraih EV untuk Pelayanan yang Memuaskan Pelanggan. Jakarta: Pustaka Delapratasa, 2000.

Philip Kotler, Pemasaran Jasa. Jakarta: Erlangga, 2002.

Rangkuti, F. Measuring Customer Satisfaction: Gaining Customer Relationship Strategy. Jakarta: Gramedia, 2003. 
Robbins, Stephen P. dan Judge. Perilaku Organisasi. Jakarta: Gramedia, 2006.

Sallis, E. Total Quality Management in Education. Yogyakarta: IRCiSoD, 2007. Sedarmayanti, Reformasi Administrasi Publik, Reformasi Birokrasi, dan Kepemimpinan Masa Depan (Mewujudkan Pelayanan Prima dan Kepemerintahan yang Baik). Bandung: Refika Aditama, 2009.

Siagian, S. P. Filsafat Administrasi. Jakarta: Gunung Agung, 1982.

Supranto, J. Metode Riset Aplikasi Dalam Pemasaran. Jakarta: Lembaga Penerbit Fakultas Ekonomi Universitas Indonesia, 1991.

Supranto, J. Pengukuran Tingkat Kepuasan Pelanggan. Jakarta: Rineka Cipta, 2006.

Tampubolon, Daulat P. Perguruan Tinggi Bermutu Baru Manajemen Pendidikan Menghadapi Tantangan Abad Ke-21. Jakarta: Gramedia, 2001.

"Teori Hierarki Kebutuhan Maslow." Diakses 5 Mei 2016. https://hinadhina39.wordpress.com/2013/04/27/teori-hierarkikebutuhan-Maslow-add-media-abraham-Maslow/.

Tjiptono, F. Manajemen Jasa. Yogyakarta: ANDI, 1998.

W., Erwan. Manajemen Kualitas Produksi Dan Jasa.Yogyakarta: Ekonisia, 2007.

Yamif, Z. Manajemen Kualitas Produk dan Jasa.Yogyakarta: Ekonisia, 2001.

Yulairmi dan Putu R. Manajemen Pelayanan Umum Di Indonesia. Jakarta: Bumi Aksara, 2007. 